\title{
Protective Role of Nigella Sativa Oil on Spermatogenesis and Testicular Structure in Cadmium Intoxicated Rats
}

\author{
Ahmad A. El-Ebiary, MarwaM. Shahin ${ }^{1}$ and Ehab M. Hantash ${ }^{2}$
}

${ }^{1}$ Departments of Forensic Medicine and Clinical Toxicology, Faculty of Medicine, Tanta University, Tanta, Egypt.
${ }^{2}$ Departments of Anatomy, Faculty of Medicine, Tanta University, Tanta, Egypt.

\begin{abstract}
Cadmium $(\mathrm{Cd})$ is a common environmental pollutant associated with many industrial processes. Considering the high sensitivity of the testicular tissue to $\mathrm{Cd}$ insult, prevention and/or therapeutic intervention is of major concern. Previous experimental evidences indicated the involvement of oxidative stress in $\mathrm{Cd}$-mediated tissue damage. The present study investigated the protective role of Nigella Sativa Oil (NSO) against the toxic effect of cadmium chloride $\left(\mathrm{CdCl}_{2}\right)$ on rat testes.Forty adult male albino rats weighing 240-280 g were assigned into four groups: Group I(Control rats), Group II (NSO-treated rats), Group III ( $\mathrm{CdCl}_{2}$-treated rats) and Group IV(rats treated with $\mathrm{CdCl}_{2}$ and $\mathrm{NSO}$ ). Cadmium chloride was injected in a dose of $2 \mathrm{mg} / \mathrm{kg}$ bw dissolved in isotonic saline intraperitoneal, whileNSO was administered in a dose of $1 \mathrm{ml} / \mathrm{kg}$ bwby gastric gavage. The present study found that administration of $\mathrm{CdCl}_{2}$ induced marked structural derangement in the seminiferous tubules of the rats' testes associated with significant drop of spermatogenesis score. Concomitant administration of NSO and $\mathrm{CdCl}_{2}$ was associated with markedreduction in the adverse structural changes seen in the testes of $\mathrm{CdCl}_{2}$-intoxicated ratsbesides preservation of spermatogenesis.
\end{abstract}

Keywords Cadmium Chloride;Nigella Sativa Oil; Rat; Testis; Spermatogenesis.

\section{Introduction}

$\longrightarrow$ admium (Cd)is a heavy metal and a common environmental and industrial pollutant that accumulates slowly in the body. Both humans and animals are exposed to $\mathrm{Cd}$ via contaminants found in air, drinking water and food (Järup\&Akesson, 2009).Cadmium is mainly used in industry for coating steel and nickel-cadmium battery production. Smoking of cigarettes and inhalation of fumes from industrial processes contribute to exposure of human population to this heavy metal (Tsalev\&Zprianov, 1993; Lawal\& Ellis, 2010).

The testis is an important target organ in acute and chronic exposure to Cd (IARC, 1993), and the nature and degree of testicular damage is usually $\mathrm{Cd}$ dependent (Waalkes, 2000).

It has been reported that $\mathrm{Cd}$ stimulates free radical generation, resulting in oxidative damage of lipids, proteins and DNA. This initiates various pathological conditions in humans and animals. The natural body free radical scavengers strongly bind to $\mathrm{Cd}$, and their consumption leads to increased generation of reactive oxygen species (ROS), a normal byproduct of aerobic respiration and a major force behind inducing oxidative stress (Kennedy et al., 2008; Ognjanovic et al., 2008).
Nigella sativa (NS), sometimes known as black seed, black cumin or Habatul-Barakah, is an annual herbaceous plant of the Ranunculaceae. It has been used traditionally for centuries in the Middle East, Northern Africa, Far East and Asia for the treatment of various diseases (Boulos, 1983).

Clinical and animal studies have shown that NSextract has many therapeutic effects including antimicrobial and antihelmintic (Agrawal et al., 1979), antibacterial (Hanafy\& Hatem, 1991), bronchodilator (El-Tahir et al., 1993), antiulcerogenic (Akhtar et al., 1996), antitumour (Worthen et al., 1998), antioxidant (Burtis\&Bucar, 2000) and anti-inflammatory (AlGhamdi, 2001)actions.

Nigella sativa has been subjected to a range of pharmacological investigations, which confirmed that TQ is the active component of the NSO (GhaliMuhtasib et al., 2006).It contains more than $30 \%$ of fixed oil and about $0.5 \% \mathrm{wt} / \mathrm{wt}$ volatile oil, which contains multiple products such as thymoquinone (TQ), nigellone and monoterpene (Nehar\& Rani, 2011).

It has been reported that NS and its derivative TQ produce antioxidant and anti-inflammatory effects through inhibiting eicosanoid generation in leucocytes, enhancing the oxidant scavenger system and 
preventing membrane lipid peroxidation (Houghton et al., 1995; Nagi et al., 1999; Salem, 2005).

This study aims to investigate the effect of acute exposure to $\mathrm{Cd}$ on rat testes, and the potential protective effect of NSO.

\section{Materials and methods Chemicals}

Cadmium chloride $\left(\mathrm{CdCl}_{2}\right)$ (analytical grade) was purchased from Sigma-Aldrich (St. Louis, MO, USA). All other chemicals used in the study were of the highest purity available, and were obtained from local commercial sources.

\section{Preparation of Nigella sativa oil}

The dried seeds of NS were purchased from the local market and were identified and authenticated in the Department of Pharmacognosy, Faculty of Pharmacy, Tanta University, Tanta, Egypt. Nigella sativa seeds were crushed and cold macerated in petroleum ether $\left(40-60{ }^{\circ} \mathrm{C}\right.$ ) for three days. Nigella sativa oil was obtained by filtration of the collected extract after evaporation of petroleum ether. Nigella sativa oil yield was $17.5 \% \mathrm{v} / \mathrm{w}$ with reference to dried seeds. The extracted NSO was preserved in screw-capped dark tubes at $-20^{\circ} \mathrm{C}$ until used (Mohamadin et al., 2010).

\section{Animals}

Forty adult male albino rats weighing 200-240 g were obtained from the Animal House of the Faculty of Medicine, Tanta University, Tanta, Egypt. They were housed under standard conditions of temperature (23 \pm $\left.2{ }^{\circ} \mathrm{C}\right)$ and lighting $(12 \mathrm{~h} \mathrm{light/dark}$ cycles $)$ and were allowed free access to food and drinking water.

\section{Ethical considerations of the study}

1- Promotion of high standard care and animal well-being at all the times.

2- Surgical or other painful procedures were performed with appropriate sedation to avoid distress and pain. The standard of care and administration met the principles expressed in the Declaration of Helsinki.

\section{Experimental design}

Animals were randomly divided into 4 equal groups (10 rats in each group). Group I rats served as a control and received $1 \mathrm{ml}$ of isotonic saline by IP injection. Group II rats were given NSO ( $1 \mathrm{ml} / \mathrm{kgbw})$ by gastric gavage (Mohamadin et al., 2010), whereas rats of group III received $2 \mathrm{mg} / \mathrm{kgbw}$ of $\mathrm{CdCl}_{2}$ dissolved in isotonic saline IP (Koyuturk et al., 2007). Group IV rats received $\mathrm{NSO}$ an hour prior to $\mathrm{CdCl}_{2}$ administration via the same routes and doses as previously described. All animals were treated daily for 8 days.

\section{Preparation of the specimens}

At the end of the experimental period, the overnightfasted rats were anaesthetized by diethyl ether. Animals were then sacrificed by cervical dislocation, dissected and their testes were removed. Specimens were taken from the testes of each animal and divided into two halves. One half was fixed in $10 \%$ formol saline, paraffin-embedded, sectioned at $5 \mu \mathrm{m}$, and prepared for light microscopic study (Olympus BX-50) using hematoxylin and eosin (H\&E) stain (Bancroft and Stevens, 1996). The other one was immersed in phosphate-buffered gluteraldehyde solution and stained with toluidine blue stain for semi-thin sections or uranyl acetate and lead citrate stains for ultra-structural examination using JEOL JEM electron microscope at 80 kilo volt (Hayat, 1989).

\section{Scoring of spermatogenesis}

The level of spermatogenesis in the testicular tissue was assessed by scoring 100 tubules per slide, and a scale from 1 to 10 was given as follows: $10=$ full spermatogenesis, $\quad 9=$ slightly impaired spermatogenesis, $8=$ few spermatozoa, $7=$ no spermatozoa but many spermatids, $6=$ few spermatids, $5=$ no spermatids but many spermatocytes, $4=$ few spermatocytes, $3=$ spermatogonia only, $2=$ no germ cells but only Sertoli cells, $1=$ atrophic tubules without seminiferous epithelial cells (Johnsen, 1970).

Data of spermatogenesis score wereentered to the computer using SPSS program for statistical analysis (version 20). Data were entered as numerical. Kolmogorov-Smirnov (D) test was used to test normality of the distribution of variables, and nonparametric statistics (minimum and maximum, median and Inter-quartile range) were done, then comparison by an over-all model using Kruskal-Wallis test was used to test several independent samples, and pair-wise comparisons between every two groups were done by Dunn-Bonferroni testto assess significance of differences between each two groups.In the present study an alpha level was set to $5 \%$ with a significance level of $95 \%$.

\section{Results}

\section{(A) Light microscopy Group I (Control rats)}

The seminiferous tubules appear round or oval in cross-sections and are separated by interstitial tissue containing blood vessels and clusters of interstitial cells of Leydig. The wall of each tubule is lined by a thick stratified germinal epithelium resting on a thin lamina propria, and their lumens are filled with spermatozoa. The stratified germinal epithelium is composed of Sertoli cells and germ cells at different stages of maturation. Spermatogonia are the first layer lying on the lamina propria with Sertoli cells scattered among them. Primary spermatocytes are the next larger cells, and spermatids are the rows of cells close to the lumen of the tubules. Spermatids mature into spermatozoa seen in the lumen of the tubules. The lamina propria contains flat, smooth muscle-like myoid cells with elongated nuclei. Spermatogonia are small, flat or dome shaped cells lying close to the lamina propria. They had ovoid or rounded nuclei, which appear pale or dark according to the chromatin distribution. Primary spermatocytes are the largest cells in the germinal epithelium that have large, spherical and vesicular nuclei with spaghetti-like chromatin. Spermatids are arranged in two to four rows close to the lumen of the tubules. Early spermatids appear small, round cells with round euchromatic, clear nuclei. They become elongated with small, dense nuclei near the lumen of the tubules. Sertoli cells nuclei appear large, elongated, basally situated, and have a large, prominent, centrally located nucleoli. Leydig cell is an acidophilic large cell with single, round or 
oval,euchromatic nucleus with prominent nucleolus (Fig. $1 \mathrm{a} \& \mathrm{~b}$ )

\section{Group II (NSO-treated rats)}

The administration of NSO produced no structural changes in the testes, which appear, more or less, similar to those of the control group (Fig. $1 \mathrm{c} \& \mathrm{~d}$ ).

\section{Group III (CdCl2-treated rats)}

Administration of $\mathrm{CdCl}_{2}$ produced severe necrosis and atrophy of the seminiferous tubules. The tubules appear separated by wide interstitial space. The lumens of many tubules are filled with defoliated and dyscohesive germ cells as well as large number of necrotic cells and debris. Other seminiferous tubules appear irregular and their lumens contain excess residual bodies and few or no spermatozoa. Some tubules show detachment of the germ cells from the underlying basement membrane. Moreover, there is also apparent reduction in the thickness of the germinal epithelium. Many germ cells appear degenerating with condensed, dark, pyknotic nuclei and cytoplasmic vacuolations (Fig. 2 a \& b).

\section{Group IV (rats treated with $\mathrm{CdCl} 2$ and NSO)}

The structural changes produced by $\mathrm{CdCl}_{2}$ became less evident with concomitant administration of NSO. Many seminiferous tubules appear normal and filled with spermatozoa. The intact germinal epithelium is formed of spermatogonia, 1ry spermatocytes, spermatids and Sertoli cells. The interstitial area and its blood vessels appear nearly normal. On the other hands, minimal changes are recognized in some other tubules. There is some reduction in the thickness of the germinal epithelium and the lumens of the tubules contain less spermatozoa and more residual bodies in comparison to the control group. There is also minimal disintegration and spacing of germ cells (Fig. 2c \&d)

\section{(B) Electron microscopy}

\section{Group I (Control rats)}

The wall of the seminiferous tubule is formed of stratified germinal epithelium and Sertoli cells. The germinal epithelium is composed of spermatogonia, 1ry spermatocytes and spermatids. These cells appear resting on a basal lamina, which is surrounded by a lamina propria. The latter contain flat smooth musclelike myoid cells with elongated nuclei. Two types of spermatogonia are seen. The pale type Aspermatogonia appear as small, flat or dome shaped cells with ovoid, pale (euchromatic) nuclei, prominent nucleoli and glycogen-poor cytoplasm. The dark type Aspermatogonia is similar to the former but with electron-dense (heterochromatic) nuclei and glycogenrich cytoplasm. Primary spermatocytes appear with large, spherical and vesicular nuclei and spaghetti-like chromatin. The mitochondria have a characteristic vacuolated appearance. Early round spermatids have clear, round nuclei and well developed acrosomal vesicles, which are filled with an electron-dense material called the acrosomal granule. The acrosomal vesicle with its acrosomal granule partially surrounds the nucleus to form the acrosome or acrosomal cap. The cytoplasm has abundant rough endoplasmic reticulum, numerous mitochondria and well developed Golgi system. The latter is formed of closely stacked, arcuate and smooth membranes containing electron- dense material. Some elongated spermatids are also seen. The nucleus covered by the acrosomal cap, appears flattened and contains condensed dark chromatin. Sertoli cell has ill-defined borders and basal, clearly visible, euchromatic nucleus with a centrally located, large and prominent nucleolus. The nuclear membrane has deep folds, which give a lobulated appearance to the nucleus. The cytoplasm contains numerous slender mitochondria. The spermatozoon is composed of a tail and head, which is occupied by a small, conical, flattened, electron-dense nucleus. The long middle piece of the tail is surrounded by a sheath of mitochondria (Fig. 3 a, b \& c).

\section{Group II (NSO-treated rats)}

The administration of NSO produced no structural changes in the in the seminiferous tubules. They appear, more or less, similar to those of the control group (Fig.3 d, e \& f).

\section{Group III ( $\mathrm{CdCl}$-treated rats)}

Administration of $\mathrm{CdCl}_{2}$ induced marked structural derangement in the seminiferous tubules. The basement membrane and lamina propria appear thick and irregular. Some spermatogonia appear detached from the basement membrane, and show marked cytoplasmic vacuolations and pyknotic nuclei. There is also widespread mitochondrial swelling indicating mitochondrial damage. Similarly, the primary spermatocytes have many cytoplasmic vacuoles. The nuclei show distortion and loss of some parts of the nuclear membrane. There are also wide intercellular spaces. The spermatids appear abnormal in structure. There is evident vacuolations and rarefaction of the nucleus as well as the cytoplasm. There is partial loss of the acrosomal cap with ill-defined acrosomal granule. The nuclei of Sertoli cells appear small and abnormally multifolded with absent nucleoli. Vacuolations are also seen in the cytoplasm. There are no spermatozoa in the lumens of the examined tubules from this group of rats (Fig. 4 a, b \& c).

\section{Group IV (rats treated with $\mathbf{C d C l} 2$ and NSO)}

Concomitant administration of $\mathrm{NSO}$ and $\mathrm{CdCl}_{2}$ was associated with significant reduction in the structural changes seen in the testes of $\mathrm{CdCl}_{2}$-treated rats. The basement membrane and lamina propria appear more regular. The spermatogonia appear normal except for less content of cytoplasmic glycogen. The primary spermatocytes also show normal features. They have large vesicular and spherical nuclei with spaghetti-like chromatin. The cytoplasm is filled with the normal and characteristic vacuolated mitochondria. The spermatids show only mild distortion of the nuclear membrane. The nucleus is related to a normal acrosomal cap. Similarly, Sertoli cells appear nearly normal. The nucleus is large, conical, euchromatic, with prominent nucleolus and indented nuclear membrane. The cytoplasm shows numerous normal mitochondria and few vacuoles. Spermatozoa are also seen in the seminiferous tubules. A transverse section in the middle piece of the spermatozoa show a normal structure composed of a central axoneme surrounded by nine dense fibers. The latter are encircled by a normal sheath of mitochondria (Fig. 4 d, e \& f). 


\section{(C) Scoring of spermatogenesis}

Johnsen score was found to be significantly decreased in Group III $\left(\mathrm{CdCl}_{2}\right.$-treated rats $)$ compared to the control rats (Group I) $(p=0.000)$. It was remarkable that concomitant administration of NSO with Cd resulted in preservation of spermatogenesis score of group IV (rats treated with $\mathrm{CdCl}_{2}$ and NSO) as shown in Tables $1 \& 2$.

Fig.1a- Showing round and oval seminiferous tubules filled with spermatozoa (Sz). The wall of each tubule is formed of many layers of germinal epithelium (S) resting on a thin lamina propria (arrow head). Spermatogonia $(\mathrm{Sg})$ are the cells close to the lamina propria. Primary spermatocytes (Ps) are the next layer of larger cells. Spermatids (Sp) form a thick layer of cells close to the lumens of the tubules. Sertoli cells (Sc) are also seen resting on the lamina propria. The tubules are separated by interstitial tissue (I) containing blood vessels (BV) and Leydig cells (L).

Fig.1b- Showing characters of different cells in the seminiferous tubules. Myoid cells (Mc) appear flat with elongated nuclei. Spermatogonia $(\mathrm{Sg})$ are small cells with oval or round, dark or pale nuclei. Primary spermatocytes (Ps) are large cells with large, round nucleus and spaghetti-like chromatin. Early spermatids (Sp) are smaller and appear as round cells with clear, spherical nuclei. The lumen contains spermatozoa $(\mathrm{Sz})$. Sertoli cell $(\mathrm{Sc})$ have large, clear nucleus with prominent nucleolus. The Leydig cells (L) are large eosinophilic cells with large, round, euchromatic nuclei and prominent nucleoli. They lie close to the blood vessels (BV) of the interstitium.

Fig.1c- Showing normal seminiferous tubules filled with spermatozoa (Sz) and separated by interstitial tissue (I). The germinal epithelium rests on a regular lamina propria (arrow head) and is formed from basal small spermatogonia $(\mathrm{Sg})$, larger 1ry spermatocytes (Ps), smaller spermatids (Sp) and Sertoli cells $(\mathrm{Sc})$.

Fig.1d- Showing small spermatogonia (Sg) with round to oval nuclei, larger primary spermatocytes (Ps) with big, spherical nuclei and spaghetti like chromatin, small round spermatids (rSp) with clear spherical nuclei and elongated spermatids (eSp) with elongated dark nuclei. Sertoli cells (Sc) have large, pear-shaped nuclei with prominent nucleoli. Flat myoid cells (Mc) are seen in the lamina propria (arrow head). Spermatozoa (Sz) fill the lumen of the tubule.

Fig.2a- Showing widespread necrosis (NE) of the tubules. Some tubules appear atrophic and have irregular wall $(\mathrm{T})$ while others are filled with necrotic debris and defoliated germ cells $(\uparrow)$. The damaged tubules are separated by dilated interstitial space (I).

Fig.2b- Showing many large residual bodies (arrow head) and many germ cells with pyknotic nuclei (red arrow). There is detachment of the germinal epithelium $(\leftrightarrow)$ from an irregular wall of the tubules (black arrow).

Fig.2c- Showing nearly normal seminiferous tubules separated by triangular interstitial spaces (I) containing normal blood vessels (BV) and Leydig cells (L). The germinal epithelium is formed of small basal spermatogonia $(\mathrm{Sg})$, middle layer of larger primary spermatocyte (Ps), inner thick layer of spermatids (Sp), and Sertoli cells (Sc). The lumens of the tubules are filled with spermatozoa $(\mathrm{Sz})$.

Fig.2d- Showing mild changes in the tubules. There is mild spacing of the germ cells (arrow head). The lumen of the tubule contains many residual bodies (red arrow) and fewer spermatozoa. Notice also the apparently reduced thickness of the germinal epithelium. Otherwise, the tubule seems normal and lined by spermatogonia (Sg), 1ry spermatocytes (Ps), spermatids (Sp) and Sertoli cells (Sc). The interstitial spaces (I) appear normal and contain normal blood vessels (BV). The germinal epithelium rests on regular lamina propria (Lp) with its myoid cells $(\mathrm{Mc})$.

Fig.3a- Showing a type A dark spermatogonium $(\mathrm{Sg})$. It has ovoid, dark nucleus $(\mathrm{N})$ with abundant heterochromatin. Its cytoplasm is rich in glycogen granules (g) and ovoid, perinuclear mitochondria $(\mathrm{m})$. It rests on a regular basement membrane (arrow head) and a lamina propria (arrow) which contains a smooth muscle-like myoid cell (MC) with elongated nucleus (n).

Fig.3b- Showing one round spermatid (Sp). It has clear, round nucleus $(\mathrm{N})$ that is partially surrounded by a normal acrosomal cap (AC). The latter contains an electron dense acrosomal granule (AG). The cytoplasm is rich in tubular mitochondria (m) and rough endoplasmic reticulum (RER). A well developed Golgi apparatus is also seen ( $\mathrm{g}$ ). It is formed of closely stacked, arcuate and smooth membranes (arrow head) containing electron-dense material (arrow).

Fig.3c- Showing longitudinal sections in different regions of some spermatozoa. The head contains a conical, flattened, electron-dense nucleus (n). The middle piece (MP) is surrounded by a sheath of mitochondria (m).

Fig.3d- Showing two normal type A dark spermatogonia $(\mathrm{Sg})$. The nuclei $(\mathrm{N})$ are oval and dark with abundant heterochromatin $(\uparrow)$. The cytoplasm is rich in oval mitochondria $(\mathrm{m})$ and glycogen granules (g). The cells are resting on normal basement membrane (BM) and lamina propria (LP).

Fig.3e- Showing one normal primary spermatocyte (Ps). The nucleus $(\mathrm{N})$ appears large, spherical, vesicular, and contains spaghetti-like chromatin. The cytoplasm is filled with characteristic vacuolated mitochondria $(\mathrm{m})$.

Fig.3f- Showing normal elongated spermatids $(\mathrm{Sp})$. The nuclei $(\mathrm{N})$ appear small, elongated, flat, and related to normal acrosomal caps (arrow head). The cytoplasm $(\mathrm{C})$ is elongated and accumulates behind the nucleus.

Fig.4a- Showing thick and irregular basement membrane (BM) and lamina propria (LP).

Fig.4b- Showing detachment $(\leftrightarrow)$ of spermatogonia $(\mathrm{Sg})$ from the basement membrane (BM).

Fig.4c- Showing an abnormal Sertoli cell (Sc) resting on a thick and irregular basement membrane (BM) and lamina propria (LP).The nucleus (n) appears small and abnormally multifolded with no nucleolus. The cytoplasm appears vacuolated (arrow).

Fig.4d- Showing a type A dark spermatogonium (sg) resting on a slightly irregular 
basement membrane (BM) and lamina propria (LP). The spermatogonium has a normal oval dark nucleus (n) and its cytoplasm contains normal mitochondria (m). Notice the less content of glycogen granules in the cytoplasm.

Fig.4e- Showing two normal primary spermatocytes (Ps). The nucleus is large, spherical and contains spaghetti like chromatin $(\mathrm{N})$. The cytoplasm is rich in characteristic vacuolated mitochondria $(\mathrm{m})$.

Table (1): Statistical analysis (Kruskal-Wallis Test) Comparison of spermatogenesis score of the studied rat groups. Each group composed of 10 rats.

\begin{tabular}{|c|c|c|c|c|}
\hline & \multicolumn{4}{|c|}{ Group } \\
\hline & $\begin{array}{c}\text { Control } \\
(n=10)\end{array}$ & $\begin{array}{c}\text { NSO } \\
(n=10)\end{array}$ & $\begin{array}{l}\mathrm{CdCl}_{2} \\
(\mathrm{n}=10)\end{array}$ & $\begin{array}{c}\mathrm{NSO}+\mathrm{CdCl}_{2} \\
(\mathrm{n}=10)\end{array}$ \\
\hline Mean & 9.40 & 9.20 & 4.30 & 7.50 \\
\hline Standard deviation & 0.699 & 0.789 & 0.949 & 1.841 \\
\hline Median & 9.50 & 9.00 & 4.00 & 7.50 \\
\hline Inter-quartile range & $9.00-10.00$ & $8.75-10.00$ & $3.75-5.00$ & $5.75-9.25$ \\
\hline KS test of normality & $\begin{array}{l}\mathrm{D}=0.305 \\
\mathrm{p}=0.009 *\end{array}$ & $\begin{array}{l}\mathrm{D}=0.245 \\
\mathrm{p}=0.091\end{array}$ & $\begin{array}{l}\mathrm{D}=0.224 \\
\mathrm{p}=0.168\end{array}$ & $\begin{array}{l}\mathrm{D}=0.113 \\
\mathrm{p}=0.200\end{array}$ \\
\hline Kruskal-Wallis Test & \multicolumn{4}{|l|}{$\begin{array}{l}X^{2}=25.736 \\
p=0.000 *\end{array}$} \\
\hline
\end{tabular}

NSO: Nigella sativa oil, CdCl 2 : Cadmium Chloride, *Significant.

Table (2): Statistical analysis (pair-wise comparisons by Dunn-Bonferroni test) of spermatogenesis score of the studied rat groups. Each group composed of 10 rats.

\begin{tabular}{|l|l|l|l|l|}
\hline & \multicolumn{4}{|c|}{ Group } \\
\hline & $\begin{array}{c}\text { Control } \\
(\mathbf{n = 1 0})\end{array}$ & $\begin{array}{c}\text { NSO } \\
(\mathbf{n = 1 0})\end{array}$ & $\begin{array}{c}\mathbf{C d C l}_{2} \\
(\mathbf{n = 1 0})\end{array}$ & $\begin{array}{c}\text { NSO + CdC2 } \\
(\mathbf{n = 1 0})\end{array}$ \\
\hline Compared to Control p value & & 0.740 & $0.000^{*}$ & $0.046^{*}$ \\
\hline Compared to NSO p value & & & $0.000^{*}$ & 0.096 \\
\hline Compared to Cd p value & & & & 0.068 \\
\hline
\end{tabular}

NSO: Nigella sativa oil, $\mathrm{CdCl}_{2}$ : Cadmium Chloride, *Significant.
Fig.4f- Showing a transverse section in the middle piece of the tail region of a spermatozoon (SZ). It has a central axoneme (A) surrounded by nine dense fibers (blue numbers) which are encircled by a sheath of mitochondria (M). Notice the presence of a spermatocyte (Ps) with its characteristic nucleus $(\mathrm{N})$ and vacuolated mitochondria $(\mathrm{m})$.
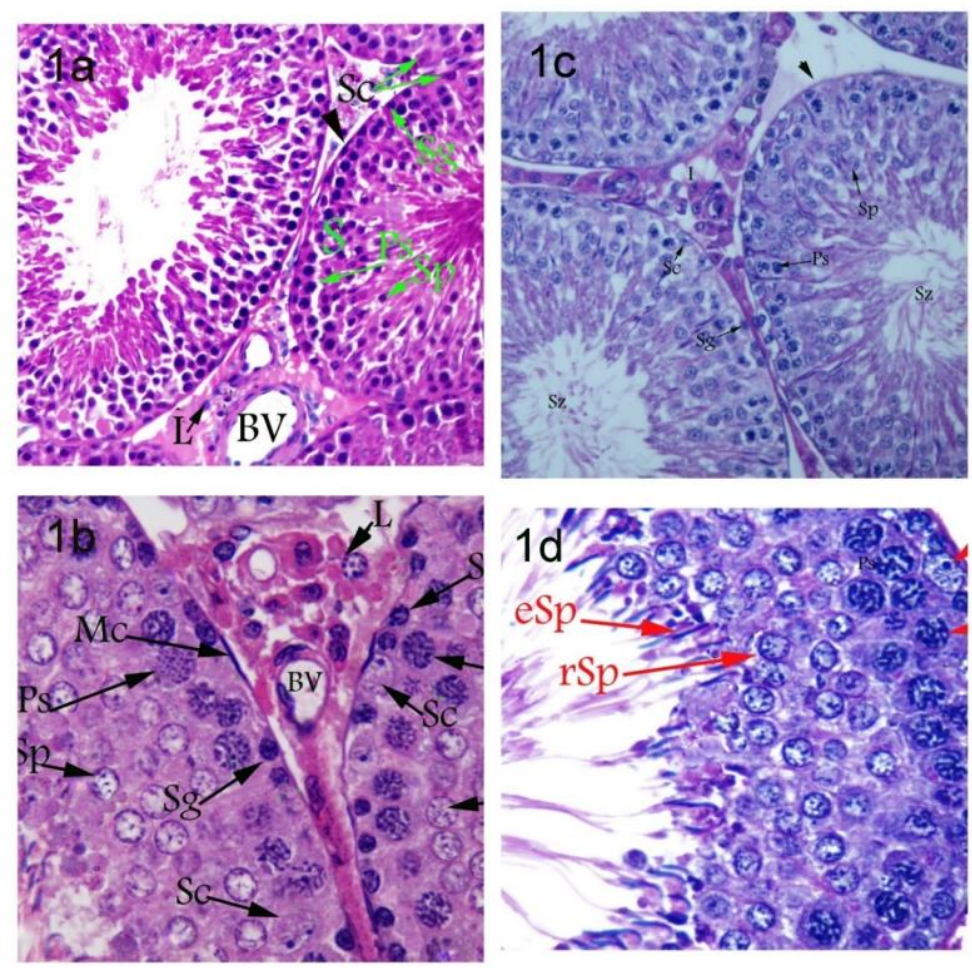

Fig. (1): $a \& b$ : Photomicrographs of sections in the testis of a control rat.(a : H\&E X 400, b:H\&E X 1000 ) c\& d: Photomicrographs of sections in the testis of a group II rat (treated with NSO).(c: H\&E X 400, d:H\&E X 1000 ) 

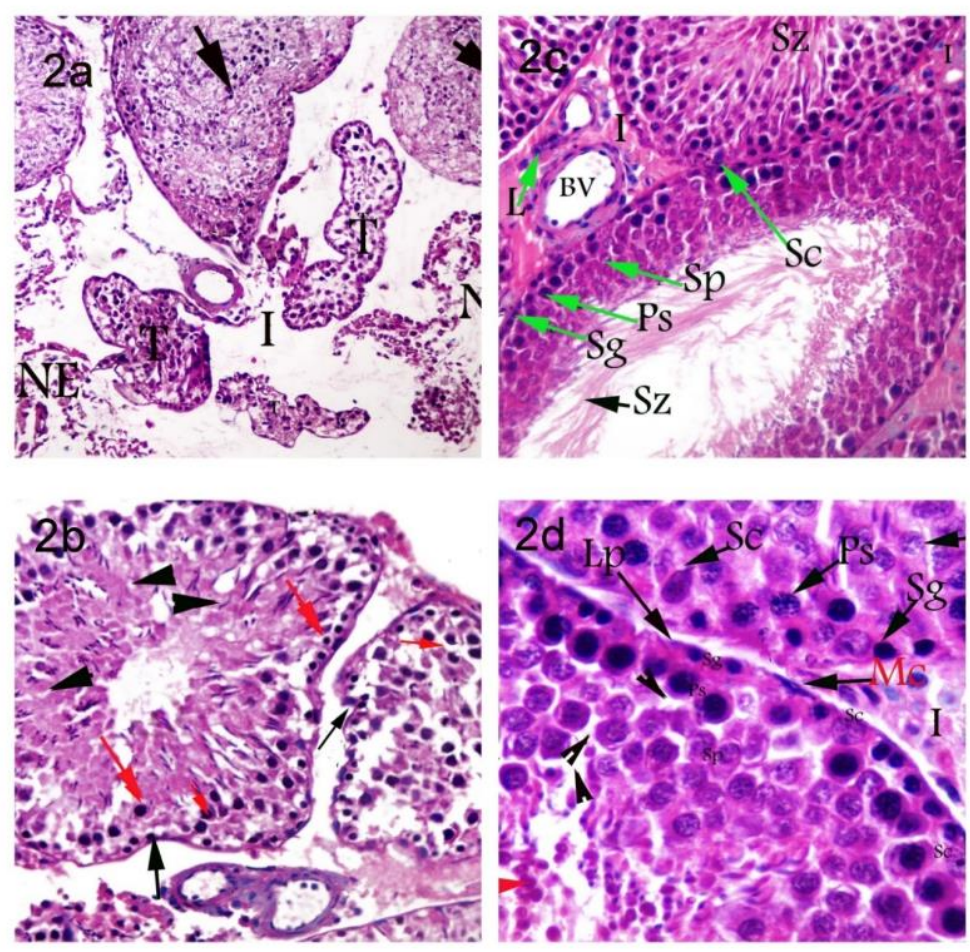

Fig. (2): a\& b: Photomicrographs of sections in the testis of group III rat (treated with CdCl2). (a: H\&E X 200, b: H\&E X 400) c\& d: Photomicrographs of sections in the testis of group IV rat (treated with CdCl2 and NSO). (c: H\&E X 400, d: H\&E X 1000)

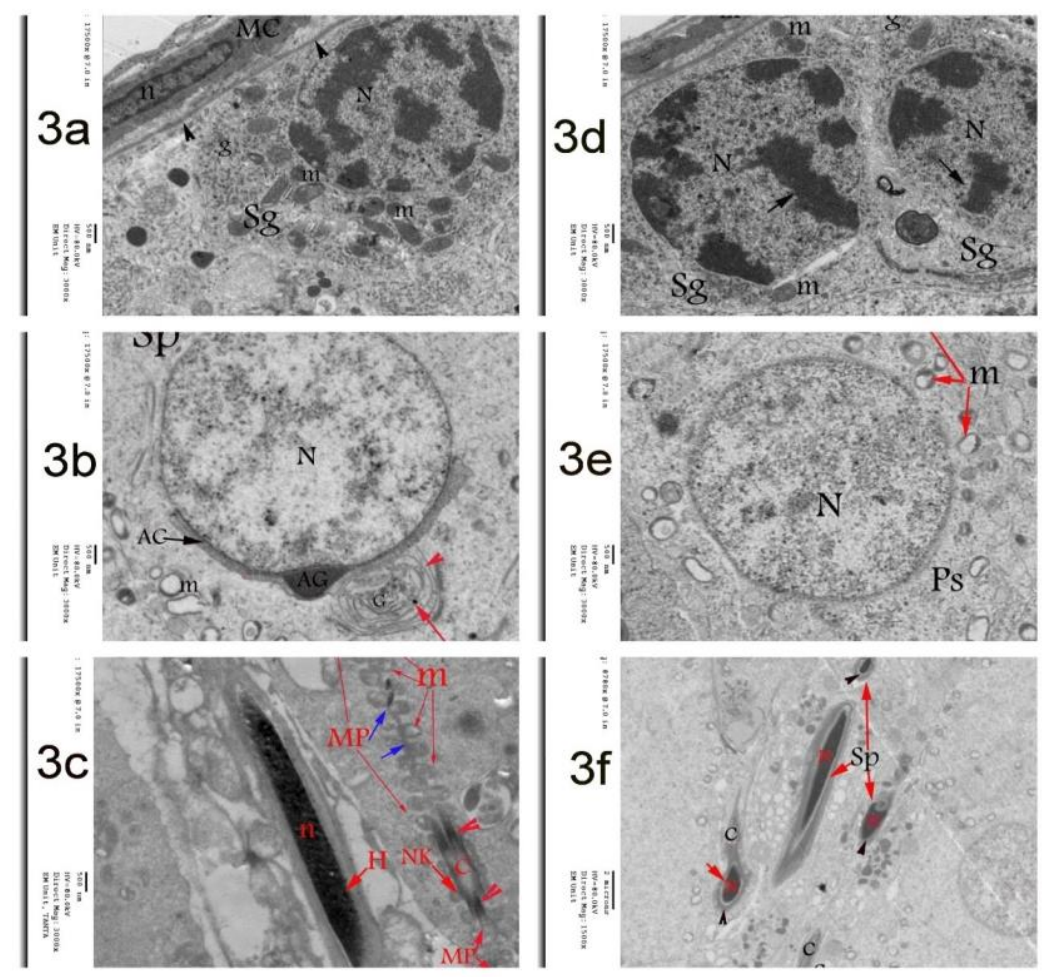

Fig. (3):a, b \& c: Electron micrographs of ultra-thin sections from a control rat testis. (EM X 3000)

d, e \& f: Electron micrographs of ultra-thin sections from the testis of a group II rat (treated with NSO).(d\& e: EM X 3000 , f:EM X 1500) 

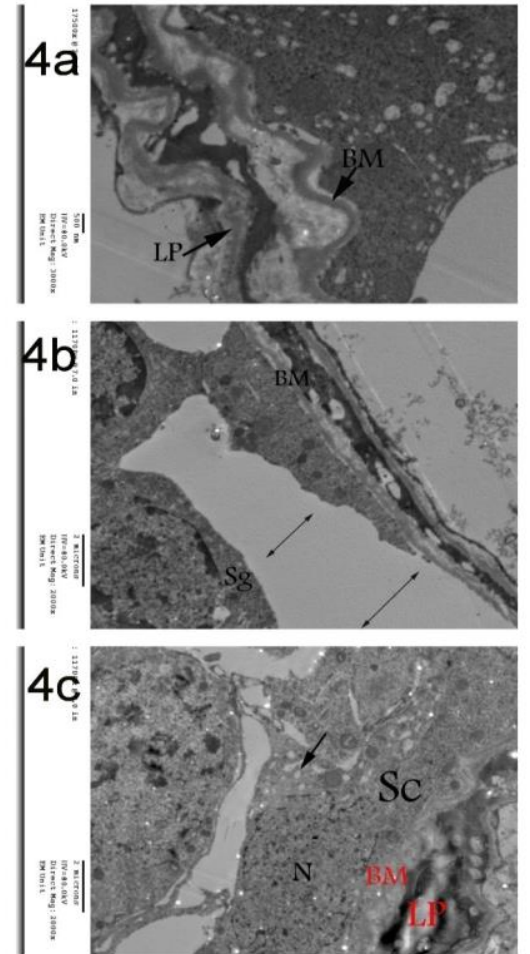

Fig. (4):

a, b \& c: Electron micrographs of ultra-thin sections from a testis of a group III rat (treated with CdCl2). (a: EM X 3000, b \& c: EM X 2000)

d, e \& f: Electron micrographs of ultra-thin sections from the testis of a group IV rat (treated with NSO and CdCl2).(EM X 3000)

\section{Discussion}

The present study investigated the effect of acute exposure to $\mathrm{Cd}$ on the rat testis in a dose of $2 \mathrm{mg} / \mathrm{kg}$ bw of $\mathrm{CdCl}_{2}$ dissolved in isotonic saline IP. The results revealed that exposure to Cdwas associated with severe degenerative changes in the seminiferous tubules, marked cytoplasmic vacuolations and pyknotic nuclei of spermatogonia, widespread mitochondrial swelling and damage together with absent spermatozoa in the lumens of the examined tubules.

The cytoplasmic vacuolations may arise from lysosomal membrane damage induced by ROS with subsequent release of lysosomal hydrolases into the cytosol, uncontrolled extra lysosomal proteolysis, enhanced autophagocytosis in the cells and tissue destructions (Skrzydlewska et al., 2001). Vacuoles may also arise from dilated or destroyed Golgi bodies, mitochondria or other cell organelles due to ionic and osmotic imbalance leading to imbibition of water causing cellular vacuolation and degeneration (ElSayed et al., 2002).

These findings are in agreement with those of Marettová et al. (2010), which showed that $\mathrm{Cd}$ administration caused widespread necrosis and vacuolization of the rat seminiferous tubular cells, interstitial tissue edema and hemorrhages.

The current study reported that concomitant administration of $\mathrm{NSO}$ and $\mathrm{CdCl} 2$ was associated with significant reduction in the structural damage seen in the testes of $\mathrm{CdCl}_{2}$-treated rats.
In the study herein, Johnsen score for assessing spermatogenesis was estimated for rats of all groups. Johnsen score for Group III $\left(\mathrm{CdCl}_{2}\right.$-treated rats) was significantly decreased in comparison to the control rats (Group I), confirming the severe adverse effects of $\mathrm{Cd}$ on both testicular structure and function. This toxic effect was apparently alleviated by concomitant administration of NSO with $\mathrm{Cd}$ as indicated by the apparent improvement of the spermatogenesis score of Group IV (rats treated with both $\mathrm{CdCl}_{2}$ and $\mathrm{NSO}$ ). Moreover, spermatogonia appeared normal except for less content of cytoplasmic glycogen and spermatozoa were seen in the lumens of the seminiferous tubules.

This result is supported by a recently published study (Fouad \&Jresat, 2015), which reported that TQ treatment noticeably ameliorated Cd-induced damage of testicular tissue and preserved spermatogenesis in most of seminiferous tubules.

Earlier studies argued the involvement of oxidative stress in Cd-mediated tissue damage. Cadmium exposure, acute as well as chronic, was associated with elevated levels of lipid peroxidation products in various tissues including the lungs, brain, kidneys, liver, erythrocytes and testes (Manca etal., 1991; Sarkar et al., 1997; Shaikh et al., 1999).Recent experimental studies have discussed the mechanism of oxidative stress and increased lipid peroxidation in testicular tissue.Depletion of antioxidant defenses and increased production of pro-inflammatory mediators 
were implicated in the pathogenesis of Cd-induced testicular toxicity (Aktas et al., 2012; Farombi et al., 2012; Fouad \&Jresat, 2013).

Mammalian sperm cells show a highly specific lipid composition with high content of polyunsaturated fatty acids, plasmalogenes and sphingomyelins. This particular structure of the sperm membrane is responsible for its flexibility and functional ability. However, lipids in spermatozoa are the main substrates for peroxidation, which may end in functional disorder of the sperm (Sikka,1996; Sanocka\&Kurpisz, 2004).

Considering the high sensitivity of the testicular tissue to $\mathrm{Cd}$ insult, prevention and/or therapeutic intervention is of major concern.Previous studies have tried to investigate the protective role of synthetic chelators and trace metals. The use of metal chelators such as dithiocarbamates and monoisoamyl meso-2,3-dimercaptosuccinate hasbeen met with limited success since their usewasassociated with chelation of essential metals from the body(Kojima et al., 1992; Yan et al., 1997).

A number of studies have found that supplementation of vitamin $\mathrm{E}$, vitamin $\mathrm{C}$, alpha-lipoic acid and beta-carotene may be effective against $\mathrm{Cd}$ induced testicular injury, may be through acting as antioxidants and free radical scavengers (Bludovska et al., 1999; El-Demerdash et al., 2004; Sen Gupta et al., 2004).

It is worth mentioning that Massadeh et al. (2007) have found that NS reduced Cd blood levels to below the detection limit in $\mathrm{Cd}$-intoxicated mice. Although the mechanism of this effect is indefinite, this striking observation has reported that NS could have a potential role in enhancing $\mathrm{Cd}$ elimination.

However, the major effect of NSO in this study might be related to TQ,itsactive ingredient with marked antioxidant activity.It acts as a direct scavenger of ROS, suppresses lipid peroxidation and enhances the activities of antioxidant enzymes catalase, SOD and glutathione transferase (Yildiz et al., 2008; SayedAhmed et al., 2010; Awad et al., 2011).In addition, TQ inhibits both cyclooxygenase and lipoxygenase, reduces the release of pro-inflammatory cytokines and exhibits significant anti-inflammatory activity (ElKhoulyet al., 2012; Umar et al., 2012; Woo et al., 2012). Inflammatory responses and activated neutrophils can increase myeloperoxidase activity. This could increase free radicals formation, enhance lipid peroxidation and worsen the tissue injury (Cetinkaya et al., 2006).

The current study concludes that NSO might be used as a safe and effective remedy for amelioration of Cd-induced testicular injury. Nigella sativa oil could be recommended for individuals at risk of industrial or environmental exposure to cadmium as a readily available plant product with no known adverse effects. However, further clinical studies may be required to verify its safety and declare its clinical application.

\section{References}

Agarwal R, Kharya MD and Shrivastava R (1979): Antimicrobial and anthelminthic activities of the essential oil of Nigella sativa Linn. Indian J. Exp. Biol. 17:1264-1265.

Akhtar AH, Ahmad KD, Gilani SN, et al., (1996): Antiulcer effects of aqueous extracts of Nigella sativa and Pongamiapinnata in rats. Fitoterapia. 38:195-199.

Aktas C, Kanter M, Erboga M, et al., (2012): Antiapoptotic effects of curcumin on cadmiuminduced apoptosis in rat testes. Toxicol. Ind. Health. 28:122-130.

Al-Ghamdi MS (2001): Anti-inflammatory, analgesic and anti-pyretic activity of Nigella sativa. J. Ethnopharmacol. 76:45-48.

Awad AS, Kamel R and Sherief MA (2011): Effect of thymoquinone on hepatorenal dysfunction and alteration of CYP3A1 and spermidine/spermine N-1-acetyl-transferase gene expression induced by renal ischaemiareperfusion in rats. J. Pharm. Pharmacol. 63(8):1037-1042.

Bancroft JD and A Stevens (1996): Theory and practice of the histological techniques. 4th edition, Churchill Livingstone, New York.

Bludovska M, Kotyzova D, Koutensky J, et al., (1999): The influence of alpha-lipoic acid on the toxicity of cadmium. Gen. Physiol. Biophys. 18:28-32.

Boulos L (1983): Medicinal plants of North Africa. Algonac: Reference Publications; Algonac, Michigan.

Burits M and Bucar F (2000): Antioxidant activity of Nigella sativa essential oil. Phytother. Res. 14(5):323-328.

Cetinkaya A, Bulbuloglu E, Kurutas EB, et al., (2006): $\mathrm{N}$-acetylcysteine ameliorates methotrexateinduced oxidative liver damage in rats. Med. Sci. Monit. 12(8):BR274-278.

El-Demerdash FM, Yousef MI, Kedwany FS, et al., (2004): Cadmium-induced changes in lipid peroxidation, blood hematology, biochemical parameters and semen quality of male rats: protective role of vitamin $\mathrm{E}$ and beta-carotene. Food Chem. Toxicol. 42:1563-1571.

El-Khouly D, El-Bakly WM, Awad AS, et al., (2012): Thymoquinone blocks lung injury and fibrosis by attenuating bleomycin-induced oxidative stress and activation of nuclear factor Kappa$\mathrm{B}$ in rats. Toxicology. 302:106-113.

El-Sayed NK, Gaafar KM, El-Ansary AK, et al., (2002): The protective potency of vitamins $\mathrm{E}$ and $\mathrm{C}$ in methanol-induced oxidative stress and retinotoxicity. J. Toxicol. Cutaneous Ocul. Toxicol. 21(4):307-327.

El-Tahir KH, Ashour MS and Al-Harbi MM (1993): The cardiovascular actions of the volatile oil of the black seed (Nigella sativa) in rats: Elucidation of the mechanism(s) of action. Gen. Pharmacol. 24:1123-1131.

Farombi EO, Adedara IA, Akinrinde SA, et al., (2012): Protective effects of kolaviron and quercetin on cadmium-induced testicular damage and endocrine pathology in rats. Andrologia. 44:273-284. 
Fouad AA and Jresat I (2013): Captopril and telmisartan treatments attenuate cadmiuminduced testicular toxicity in rats. Fundam. Clin. Pharmacol. 27:152-160.

Fouad AA and Jresat I (2015):Thymoquinone therapy abrogates toxic effect of cadmium on rat testes. Andrologia. 47(4):417-426.

Gali-Muhtasib H, EL-Najjar N and Schneider-Stock R (2006): The medicinal potential of black seed (Nigella sativa) and its components. Adv. Phytomedicine. 2:133-153.

Hanafy MS and Hatem ME (1991): Studies on the antimicrobial activity of Nigella sativa seed (black cumin). J. Ethmopharmacol. 34:275278.

Hayat MA (1989): Principles and Techniques of Electron Microscopy: Biological Applications. Macmillan Press Scientific and Medical, Basingstoke and London UK.

Houghton PJ, Zarka R, De Las Heras B, et al., (1995): Fixed oil of Nigella sativa and derived thymoquinone inhibit eicosanoid generation inleukocytes and membrane lipid peroxidation. Planta Med. 61:33-36.

IARC (1993): Beryllium, cadmium, mercury and exposures in the glass manufacturing industry. In: IARC Monographs on the Evaluation of Carcinogenic Risk of Chemicals in Humans. Vol. 58, IARC Scientific Publication, International Agency for Research on Cancer, Lyon, pp.119-237.

Järup L and Akesson A (2009): Current status of cadmium as an environmental health problem. Toxicol. Appl. Pharmacol. 238:201-208.

Johnsen SG (1970): Testicular biopsy score count - a method for registration of spermatogenesis in human testes: normal values and results in 335 hypogonadal males. Hormones. 1:2-25.

Kennedy PJ, Vashisht AA, Hoe KL, et al., (2008): Genome-wide screen of genes involved in cadmium tolerance in Schizosaccharomycespombe. Toxicol. Sci. 106(1):124-139.

Kojima S, Sugimura Y, Hirukawa H, et al., (1992): Effects of dithiocarbamates on testicular toxicity in rats caused by acute exposure to cadmium. Toxicol. Appl. Pharmacol. 116:2429.

Koyuturk M, Yanardag R, Bolkent S, et al., (2007): The potential role of combined anti-oxidants against cadmium toxicity on liver of rats. Toxicol. Ind. Health. 23(7):393-401.

Lawal AO and Ellis E (2010): Differential sensitivity and responsiveness of three human cell lines HepG2, 1321N1 and HEK 293 to cadmium. J. Toxicol. Sci. 35:465-478.

Manca D, Ricard AC, Trottier B, et al., (1991): Studies on lipid peroxidation in rat tissues following administration of low and moderate doses of cadmium chloride. Toxicology. 67:303-323.

Marettová E, Maretta M and Legáth J (2010): Changes in the peritubular tissue of rat testis after cadmium treatment. Biol. Trace Elem. Res. 134:288-295.

Massadeh AM, Al-Safi SA, Momani IF, et al., (2007): Analysis of cadmium and lead in mice organs: effect of Nigella sativa L. (Black Cumin) on the distribution and immunosuppressive effect of cadmium-lead mixture in mice. Biol. Trace Elem. Res. 115(2):157-167.

Mohamadin AM, Sheikh B, Abd El-Aal AA, et al., (2010): Protective effects of Nigella sativa oil on propoxur-induced toxicity and oxidative stress in rat brain regions. Pest. Biochem. Physiol. 98(1):128-134.

Nagi MN, Alam K, Badary OA, et al., (1999): Thymoquinone protects against carbon tetrachloride hepatotoxicity in mice via an antioxidant mechanism. Biochem. Mol. Biol. Int. 47:153-159.

Nehar S and Rani P (2011): HPTLC studies on ethanolic extract of Nigella sativa Linn. seeds and its phytochemical standardization. The Ecoscan. 1:105-108.

Ognjanovic BI, Markovic SD, Pavlovic SZ, et al., (2008): Effect of chronic cadmium exposure on antioxidant defense system in some tissues of rats: protective effect of selenium. Physiol. Res. 57(3):403-411.

Salem ML (2005): Immunomodulatory and therapeutic properties of the Nigella sativa L. seed. Intern. Immunopharmacol. 5:1744-1770.

Sanocka D and Kurpisz M (2004): Reactive oxygen species and sperm cells. Reprod. Biol. Endocrinol. 2:1-7.

Sarkar S, Yadav P and Bhatnagar D (1997): Cadmiuminduced lipid peroxidation and the antioxidant system in rat erythrocytes: the role of antioxidants. J. Trace Elem. Med. Biol. 11:813.

Sayed-Ahmed MM, Aleisa AM, Al-Rejaie SS, et al., (2010): Thymoquinone attenuates diethylnitrosamine induction of hepatic carcinogenesis through antioxidant signaling. Oxid. Med. Cell. Longev. 3(4):254-261.

Sen Gupta R, Kim J and Gomes C, et al., (2004): Effect of ascorbic acid supplementation on testicular steroidogenesis and germ cell death in cadmium-treated male rats. Mol. Cell Endocrinol. 221:57-66.

Shaikh ZA, Vu T and Zaman K (1999): Oxidative stress as a mechanism of chronic cadmium induced hepatotoxicity and renal toxicity and prevention by antioxidants. Toxicol. Appl. Pharmacol. 154:256-263.

Sikka SC (1996): Oxidative stress and role of antioxidant in normal and abnormal sperm function. Front Biosci. 1:78-86.

Skrzydlewska E, Dobrzynska I, Kasacka I, et al., (2001): Effect of Vitamin E Derivative (U83836E) on Membranes of Rat Liver Cells after Methanol Intoxication. Pol. J. Environ. Stud. 10(2):95-100.

Tsalev DL and Zprianov ZK (1993): Atomic Absorption spectrometry in occupational and 
environmental health practice. CRC press, Boca Raton: FL. USA, pp. 105.

Umar S, Zargan J, Umar K, et al., (2012): Modulation of the oxidative stress and inflammatory cytokine response by thymoquinone in the collagen induced arthritis in Wistar rats. Chem. Biol. Interact. 197:40-46.

Waalkes MP (2000): Cadmium carcinogenesis in review. J. Inorg. Biochem. 79:241-244.

Woo CC, Kumar AP, Sethi G, et al., (2012): Thymoquinone: potential cure for inflammatory disorders and cancer. Biochem. Pharmacol. 83:443-451.
Worthen D, Ghosheh O and Crooks P (1998): The in vitro anti-tumor activity of some crude and purified components of black seed Nigella sativa L. Anticancer Res. 18:1527-1532.

Yan H, Carter C, Xu C, et al., (1997): Cadmiuminduced apoptosis in the urogenital organs of the male rat and its suppression by chelation. J. Toxicol. Environ. Health. 52:149-168.

Yildiz F, Coban S, Terzi A, et al., (2008): Nigella sativa relieves the deleterious effects of ischemia reperfusion injury on liver. World $\mathrm{J}$. Gastroenterol. 14(33):5204-5209.

\section{الملخص العربح}

\section{الدور الوقائي لزيت الحبة السوداء على تكوين الحيوانات المنوية و بنية الخصية في الجرذان المسممة بالكادميوم}

\section{د. أحمد عبد الستار الإبيارى و د. مروة محمد شاهين ا و د. إيهاب محمد هنطشץ}

يعد الكادميوم من الملوثات البيئية الشائعة والتي ترتبط بالعديد من الصناعات، ونظرالحساسية أنسجة الخصية العاليةلتأثر بالكادميوم فإن البحث عن وقاية أو علاج هو محط اهتمام كبير، وقد أشارت الأدلةالتجريبيةالسابقةإلى تورط الأكسدة في تلف الأنسجة الناشيء عن الكادميوم.

وقد بحثت هذه الدراسة الدور الوقائي لزيت الحبة السوداء ضد الآثار الضارة للتعرض للكادميوم على خصية

وقد استخدم أربعون منذكور الجرذان البيضاءالبالغة تزن · ؟ ؟- • ب غرام في هذه الدراسة، وقسمت إلى أربع بحموعات: الجمموعة الأولى (البحموعة الضابطة)، البحموعة الثانية (الجرذانالمعالجة بزيت الحبة السوداء)، البمموعة الثالثة (الجرذانالمعالجة بكلوريد الكادميوم)والبحموعة الرابعة (الجحرذانالمعالجة بكلوريد الكادميوم بالإضافة الى زيت الحوعيت الحبة السوداء)، وتم إعطاء كلوريد الكادميوم بجرعة ب بحم/كجم من وزن الجسم مذابا في محلول ملحي عن طريق الحقن داخل البريتون،

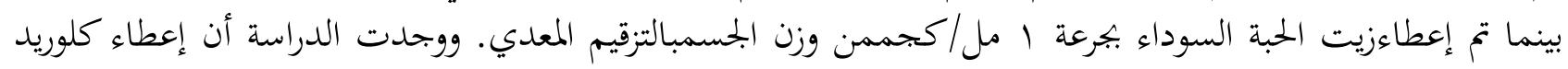
الكادميوم قد أحدث اضطرابا ملحوظا في تركيب الأنابيب المنوية للصية الجرذان مرتبطا بانغفاض كبير في معدل تصنيع الحيوانات المنوية،

و قد صاحب إعطاء زيت الحبة السوداء مع كلوريد الكادميوم تحسنا ملحوظافي التأثيرات السلبية لكلوريد

الكادميوم على نسيتج الخصيتين، بالإضافة إلى حفظ القدرة على إنتاج الحيوانات المنوية في الجرذانالمسممة بالكادميوم. 